Ryszard BARTNiK, Leszek Drong,

Matgorzata Zduniak-Wiktorowicz

Uniwersytet im. Adama Mickiewicza w Poznaniu, Uniwersytet Śląski w Katowicach, Uniwersytet im. Adama Mickiewicza w Poznaniu

\title{
Krzywe lustra kryzysu? Konflikty i podziały społeczno- -polityczne związane z brexitem we współczesnych powieściach z Wysp Brytyjskich
}

\section{Od kryzysu dyskursu do kryzysu prawdy i wartości}

Poddanie wnikliwej i wyczerpującej refleksji samego zjawiska brexitu stanowiącego bezpośrednią konsekwencję brzemiennego w skutki referendum z 23 czerwca 2016 roku w Zjednoczonym Królestwie to wciąż jeszcze niezwykle istotne i nie do końca zrealizowane zadanie intelektualne. Tymczasem już w najbliższych dniach możemy spodziewać się monograficznych opracowań na temat literatury postbrexitowej. Pod koniec sierpnia 2021 roku ukazała się ${ }^{1}$ praca Kristiana Shawa pt. Brexlit: British Literature and the European Project zapowiadana jako studium takiej właśnie prozy (tj. „post-brexit fiction” - Shaw 2021). „Europejski projekt” w podtytule książki Shawa to nawiązanie do sytuacji kryzysowej, jaka doprowadziła do opuszczenia Unii Europejskiej przez Zjednoczone Królestwo Wielkiej Brytanii i Irlandii Północnej. Ale to także sugestia, że kryzys tożsamościowy, polityczny, społeczny, a być może także gospodarczy, na który od 2020 roku nałożyła się dodatkowo pandemia SARS-CoV-2, dotyczył i nadal dotyczy wielu innych krajów starego kontynentu poza Wyspami Brytyjskimi. Chcemy w tym artykule przyjrzeć się wybranym literackim obrazom tego kryzysu, skupiając uwage głównie na prozie anglojęzycznej, a inspiracji do krytycznego oglądu literatury szukając w opracowaniach socjologicznych

1 Poniższy artykuł został przygotowany w ostatecznej wersji na początku sierpnia 2021 roku. 
i politologicznych. Naszym celem jest bowiem spojrzenie na współczesną kulturę na Wyspach Brytyjskich przez pryzmat rzeczywistości społeczno-politycznej, w której jest osadzona - traktujemy zatem historyczne okoliczności brexitu jako klucz do selekcji i eskploracji tekstów literackich. Powieści brytyjskie i irlandzkie ostatnich lat zamierzamy zatem umieścić w porządku dyskursu społeczno-politycznego współkształtowanego przez pisarzy jako komentatorów oraz - niejednokrotnie - wieszczów okołobrexitowego kryzysu.

Warto pamiętać, że kryzys to w pierwotnym sensie punkt zwrotny, moment na podejmowanie kluczowych decyzji (z grec. крíбı, krisis), czas osądu przeszłości i wyboru drogi na przyszłość. Takim punktem zwrotnym dla Europy, jak pisze Karl Schlögel w książce Im Raume lesen wir die Zeit. Über Zivilisationsgeschichte und Geopolitik (W przestrzeni czas czytamy. O historii cywilizacji i geopolityce), był rok 1989. Jego symbolicznym wyrazem stał się upadek muru berlińskiego (jakże to znamienne w kontekście brexitu). W swym niewątpliwie pozytywnym wymiarze ten akt (de)konstrukcji, w dosłownym tego słowa znaczeniu, stał się początkiem „rewolucji przestrzennej”. Z jednej strony był to czas niepewności, ale także, a może przede wszystkim, czas „nadziei”. Uczestnicy tych wydarzeń, Europejczycy sensu largo, stali się „naocznymi świadkami przechodzenia świata z jednego stanu w inny, z Przed w Po" (Schlögel 2009: 23). Spojrzenie w przeszłość było tylko i aż punktem wyjścia do afirmacji tego, co ma nadejść, co w ramach wspólnoty europejskiej chcieliśmy i potrafiliśmy (z)budować. $\mathrm{Na}$ przestrzeni ostatnich lat możemy ponownie mówić o rewolucji przestrzennej, jednakże jej kolejna odsłona ma już bardziej niepokojący charakter i wskazuje na dekonstrukcję naznaczoną rozpadem.

Podjęta współcześnie, już po referendum w Zjednoczonym Królestwie w 2016 roku, refleksja nad kryzysami i kwestiami tożsamościowymi nie tylko na Wyspach Brytyjskich, ale w całej Europie przekłada się na dyskursy literackie oraz na zaangażowanie autorów w debaty społeczno-polityczne, wychodzące daleko poza tradycyjnie rozumiane pole tekstowe. Andrzej Skrendo w artykule Pisarz jako przewodnik duchowy zastanawia się nad współczesnym statusem artysty/pisarza/poety. Dawniej był on depozytariuszem prawdy duchowej o tym, „co jakoby straciliśmy”. Dziś, jak podkreśla Skrendo, „wchodzenie w dawne role [...], czyli rolę przewodnika, staje się czymś szczególnie rażącym i anachronicznym”. Pojawia się jednak pytanie, „czy aby na pewno” (Skrendo 2019: 29), zwłaszcza jeśli weźmiemy pod uwagę konieczność zdiagnozowania stanu społeczeństw europejskich ze szczególnym uwzględnieniem społeczno-politycznego rozwibrowania, które wzmacnia narodowe egoizmy i animozje. Analizy tego rodzaju pisarstwa odnajdziemy w redagowanym przez Roberta Eaglestone'a opracowaniu pt. Brexit and Literature: Critical and Cultural Responses 
(Brexit i literatura. Krytyczne i kulturowe reakcje) poświęconym tymże związkom (Eaglestone, red. 2018).

W jednym z zamieszczonych tam kluczowych esejów o znamiennym tytule Do Novels Tell Us How to Vote? (Czy powieści mówią nam, jak głosować?) Sara Upstone koncentruje swą uwagę na sprawczości literatury w kontekście przemian społeczno-politycznych dwóch pierwszych dekad xxi wieku na Wyspach Brytyjskich. Teksty literackie, szczególnie te nośne i wpływowe, trudno postrzegać w oderwaniu od „polityki wyobrażeń kulturowych"2 (Upstone 2018: 48) właściwej dla danego społeczeństwa. Zdaniem Upstone literatura pozwala zrozumieć, dlaczego „wynik referendum nad opuszczeniem Unii Europejskiej nie jest klęską sam w sobie - to zaledwie objaw katastrofy wewnętrznych podziałów, rozczarowania i rozpaczy, które stały się udziałem Brytanii” (Upstone 2018: 54). Znamienne jest także to, że w swojej uogólniającej diagnozie Upstone wspomina wyłącznie o Brytanii, pomijając Irlandię Północną, również zmuszoną głosami Brytyjczyków do opuszczenia Unii Europejskiej. Wrócimy jeszcze do tego irlandzkiego wątku w dalszej części niniejszego artykułu.

Związek współczesnych konfliktów i nowych podziałów (a także zaostrzenia wcześniejszych) z językiem wydaje się oczywisty. W kontekście przemian społeczno-politycznych w Europie skupiamy się tu - i w całym numerze - na ilustracjach i odpowiedziach literackich na kryzys już zaistniały, ale warto pamiętać, że rozmaite dyskursy - choćby zabiegi socjotechniczne związane z propagandą, modelowanie pamięci zbiorowej w ramach polityki historycznej, reklama podprogowa i techniki perswazyjne wykorzystujące jako nośnik media społecznościowe czy kształtowanie określonego popytu za pomocą kultury popularnej, w tym literatury - ponoszą odpowiedzialność za obecny stan rzeczy. Tworząc dyskursywne szybolety, które zastępują wnikliwą analizę i dogłębne poznanie europejskich sąsiadów, angielscy nacjonaliści łatwo podzielili rasę ludzką, a przynajmniej europejską wspólnotę na Swoich i Innych. To zjawisko adekwatnie opisuje Francis Fukuyama, mówiąc o „patriotach”, którzy obierają za swój główny cel „ochronę tradycyjnej tożsamości narodowej”. Podstawowym narzędziem potrzebnym do jego realizacji jest „polityka niechęci” (ang. the politics of resentment) (Fukuyama 2019: 7), która opiera się na binarnym podziale na to, co „nasze”, a więc bardziej wartościowe i prawdziwsze w sensie tożsamościowym, oraz „obce”, a więc zagrażające integralności „naszego świata”. W tym kontekście kłamstwo i manipulacja - jako zjawiska zarówno językowe, jak i moralne - najwyraźniej stały się uprawnionymi i trudnymi do zakwestionowania narzędziami kształtowania rzeczywistości.

2 Tłumaczenie obcojęzycznych tekstów, jeśli nie zaznaczono inaczej, pochodzi od autorów artykułu. 
Wyczerpujący obraz wpływu języka na ewolucję postaw politycznych na Wyspach Brytyjskich daje monografia Steve'a Buckledee pt. The Language of Brexit: How Britain Talked Its Way Out of the European Union (Język brexitu. Jak Brytania przekonała samą siebie do wyjścia z Unii Europejskiej). Trzynasty, bodaj najistotniejszy rozdział tej pracy zaczyna się od omówienia związku pojęcia postprawdy z określeniem Brexiteer odnoszącym się do zadeklarowanego zwolennika brexitu (Buckledee 2018: 151). Oczywiście zanik skrupułów moralnych wśród wielu przedstawicieli klasy politycznej w dobie powszechnej dezinformacji oraz wszechwładzy fake newsów to zjawisko znacznie wcześniejsze, ale trzeba było wygranej Donalda Trumpa w wyborach prezydenckich w Us A w 2016 roku, a nieco wcześniej sukcesu nacjonalistów angielskich (za jaki należy uznać wynik referendum z 23 czerwca 2016 roku), żeby zrozumieć, jak silny jest wpływ nacechowanego szowinizmem, rasizmem i imperialnymi kompleksami dyskursu skrajnej prawicy w pozornie demokratycznych państwach na całym świecie. Głębsze wyjaśnienie tych zjawisk jest szczególnie istotne i pożądane, biorąc pod uwagę, z jak dramatycznym zwrotem społecznym, kulturowym i politycznym mamy tu do czynienia. Jeszcze nie tak dawno społeczeństwo brytyjskie było skłonne dokonywać zgoła innych wyborów. Ich emanacją, w sensie politycznym, był Tony Blair, który tak oto opisywał więzy, jakie łączyły (dla niektórych nadal łączą) jego kraj z resztą kontynentu:

Za moją motywacją, aby zakotwiczyć Brytanię w centrum Europy, nie krył się łzawy idealizm, choć podzielam ideę (zjednoczonej) Europy; był nią po prostu interes narodowy. W nieodległej przyszłości, która nadchodzi wielkimi krokami, żaden europejski naród nie będzie w stanie sprostać presji wywieranej przez naprawdę wielkie kraje, bez tworzenia więzi z innymi narodami. Zjednoczeni jesteśmy silni. Podzieleni jesteśmy słabi (Blair 2010: 502).

Dekadę później podział stał się faktem, a konsekwencje tego są, jak się wydaje, dopiero przed nami.

\section{Zjednoczone Królestwo - bezpowrotnie utracona wspólnota?}

O współczesnych realiach społeczno-politycznych Zjednoczonego Królestwa wiele mówi literatura przyglądająca się zarówno od środka, jak i z pewnego dystansu kulturowego sytuacji na Wyspach Brytyjskich i w całej Europie. I tak, już po referendum brexitowym, w 2017 roku ukazała się książka pt. Exit West (Drzwi na zachód) Palestyńczyka Mohsina Hamida, autora bestsellerowego 
Uznanego za fundamentalistę. To powieść o migracjach i kryzysie asymilacji, a u źródeł decyzji o opuszczeniu domu i wyruszeniu w nieznane leży, zdaniem Hamida, obawa o samo istnienie, strach przed śmiercią z rąk zamachowców, wrogów, a czasem po prostu przed bliżej nieokreślonym złem. Drzwi na zachód opowiada również o miłości w czasach kryzysu tożsamości potrzebującej stabilnego punktu odniesienia. Dwoje głównych bohaterów poznaje się w okolicznościach przypominających sytuację we współczesnej Syrii, w miastach takich jak Aleppo:

Może zdawać się dziwne, że w miastach na krawędzi upadku młodzi ludzie wciąż uczęszczali na lekcje [...], ale tak to już jest, i z miastami, i z samym życiem, w jednej chwili krzątamy się jak zwykle wokół własnych spraw, a w następnej umieramy, a nasz stale i nieuchronnie zbliżający się kres ani na chwilę nie zatrzymuje tych przelotnych chwil początkowych i pośrednich aż do momentu, kiedy wreszcie to uczyni (Hamid 2018: 1).

Opis Hamida sugeruje punktowy chartakter kryzysu jako momentu, który niczym doświadczenie graniczne - wyrywa nas z codzienności i każe skonfrontować się $\mathrm{z}$ fundamentalnymi aspektami egzystencji. $\mathrm{W}$ samej fabule powieści kryzys ten rozpisany jest na fazy i etapy symbolizowane przechodzeniem przez kolejne drzwi stanowiące portale do innego świata, innego, ale wciąż tak samo boleśnie naznaczonego współczesnymi problemami.

W wielu współczesnych powieściach opisujących stan kryzysu akcent pada na jego longue durée, długotrwałą obecność w świadomości ludzi dotkniętych negatywnymi skutkami. Obecna sytuacja epidemiologiczna, pierwotnie zapowiadająca się na tygodnie, najwyżej miesiące, przeciąga się w kryzys społeczno-gospodarczy znacznie trudniejszy do uchwycenia, asymptotycznie zbliżający się do pozorów normalności. Locus classicus takich okoliczności znajduje się w Oranie opisanym mistrzowskim piórem Alberta Camusa. Jego dżuma (a właściwie: Dżuma, w oryginale La Peste, czyli zaraza lub plaga), podobnie jak alegorycznie z nią kojarzona druga wojna światowa, nie była doświadczeniem punktowym, chwilową konfrontacją z niewytłumaczalnym i niemożliwym do zaakceptowania. Zmuszała do pokornego oczekiwania na rozstrzygnięcie, kulminację, ostateczny wybór: śmierć lub życie. Trwanie zarazy było gorsze niż najokrutniejsze nawet rozwiązanie przyszłości mieszkańców Oranu.

Trudno nie wracać myślami do Dżumy Camusa, nie tylko dlatego, że pandemia wciąż dziesiątkuje Europę i resztę świata. Brexit, choć kontrowersyjnie to zabrzmi, ma podobny do fabuły Camusa potencjał uwypuklania skrajnych 
postaw i stawiania ludzi w sytuacjach granicznych. Jako jeden z najpoważniejszych kryzysów wspólnoty europejskiej pod wieloma względami przypomina nastroje opisane przez francuskiego myśliciela tuż po drugiej wojnie światowej. Odczucia związane z ponad czteroletnim okresem, jaki upłynął od referendum do zakończenia okresu przejściowego, dobrze oddaje poręczny zwrot Borisa Johnsona z kampanii przed brytyjskimi wyborami w 2019 roku: „Get Brexit done!” (O’Toole 2020: ix; Sobolewska, Ford 2020: 287; Perrigo 2019). Niech się wreszcie stanie! Dość czekania i trwania w niepewności, podejmijmy jakąś decyzję, nieważne nawet jaką, ale chcemy wreszcie znaleźć się po drugiej stronie portalu $z$ odpowiedzią na podstawowe pytanie: co będzie dalej. Na emocje i niepewność, które są związane z momentem przejścia/zmiany wskazuje Anne Applebaum w książce Twilight of Democracy. The Seductive Lure of Authoritarinism (Zmierzch demokracji. Zwodniczy powab autorytaryzmu). Według niej, Brytyjczycy, opuszczając struktury Unii Europejskiej, postanowili zredefiniować siebie jako narodową wspólnotę. Odpowiadając sobie na pytanie, kim są, postanowili, zwłaszcza w ramach dyskursu politycznego, doprecyzować ramy „brytyjskości”, a w istocie angielskiego esencjalizmu. Applebaum zastanawia się, czy mają oni rzeczywiście powody do konstruktywnego optymizmu, biorąc pod uwagę, iż sytuacja Zjednoczonego Królestwa po brexicie, a w szczególności po kryzysie „zdrowotnym i ekonomicznym roku 2020”, może spowodować, że to, co się „wyłoni”, będzie „odmienne” od ich oczekiwań (Applebaum 2020: 104). Liczne utwory literackie napisane i opublikowane w ostatnich latach skupiają się właśnie na takim oczekiwaniu, mniej lub bardziej alegorycznie odnosząc się do kwestii nie tylko geopolitycznego, ale i egzystencjalnego zawieszenia oraz niepewności.

Spójrzmy na kilka reprezentatywnych przykładów. Klasyczny powieściowy „raport o stanie państwa” (ang. a state of the nation novel) można znaleźć w Middle England pióra Jonathana Coe’a z 2018 roku. To tradycyjna powieść $\mathrm{z}$ elementami satyry, ale też parodii (nawiązująca już w samym tytule do twórczości J.R.R. Tolkiena), w której autor kreśli obraz nastrojów, aspiracji i napięć towarzyszących społeczeństwu brytyjskiemu przez niemal całą drugą dekadę XxI wieku. Coe podejmuje próbę odpowiedzi na pytanie, co kierowało Brytyjczykami podczas głosowania 23 czerwca 2016 roku, kiedy wykuwała się przyszłość Zjednoczonego Królestwa. Nie jest to odpowiedź socjologa, a raczej obserwatora, który przedstawia losy kilkunastu postaci zanurzonych w realistycznie opisaną codzienność Londynu, Birmingham i okolic. Jedna z nich narzeka jeszcze przed referendum na "ducha naszych czasów” naznaczonego „radykalnym niezdecydowaniem” (radical indecision) (Coe 2018: 35). To właśnie tego ducha chce uzdrowić Johnson swoimi kategorycznymi decyzjami 
i zero-jedynkową retoryką (Sobolewska, Ford 2020: 293; Hesk 2019). Ale nawet premier Zjednoczonego Królestwa nie jest w stanie zatrzymać procesu narastania podziałów wewnątrz brytyjskiego społeczeństwa.

Jedna $\mathrm{z}$ bohaterek powieści Coe’a odnosi się do tych podziałów, podkreślając różnice narosłe między Brytyjczykami za pomocą metafory ściany czy wręcz muru. W tym ujęciu warto raz jeszcze sięgnąć do Schlögla, który opisując miejsce po murze berlińskim, podkreśla, że wspomnienie o nim stanowi ważny punkt odniesienia, gdyż „przypomina o dawnej granicy”. Najważniejsze w tym kontekście jest jednak to, iż „trzeba niemalże fantazji [...], żeby wyobrazić sobie tamtą Europę, która obecnie (pod koniec pierwszej dekady lat dwutysięcznych) wróciła do normalności” (Schlögel 2009: 25). Z perspektywy roku 2021 jest oczywiste, że to właśnie logika podziałów, (samo)izolacji i odgradzania się ma szansę stać się „nową normalnością”. I to właśnie figura muru w różnych odsłonach, często powiązana $\mathrm{z}$ kulturową/społeczną/polityczną granicą i fortyfikacją obronną, niejednokrotnie pojawia się w dyskursie literackim po referendum z 2016 roku. W Middle England Sophie zdaje sobie sprawę z różnic pokoleniowych, światopoglądowych, charakterologicznych i - last but not least - politycznych. Co do samej siebie i swojej teściowej nie ma wątpliwości, że:

Może i mieszkały tuż obok siebie, w tym samym kraju, ale jednocześnie zamieszkiwały odmienne wszechświaty, a te wszechświaty oddzielał mur, nieskończenie wysoki i nieprzenikalny, mur zbudowany ze strachu i podejrzeń, a może też z odrobiny tych najbardziej typowych angielskich przymiotów - wstydu i skrępowania (Coe 2018: 90).

Ten mur, figuratywnie antycypowany przez Sophie jeszcze w 2011 roku, będzie rósł przez lata, aż doprowadzi do nieodwracalnej tragedii podobnej do tej, jaką było morderstwo posłanki Partii Pracy, Jo Cox, tuż przed referendum brexitowym.

Równie mroczny obraz Wysp Brytyjskich po apokalipsie brexitowej można znaleźć w dystopijnej powieści Johna Lanchestera pt. The Wall, czyli właśnie mur. Ta przypowieść o konfrontacji z własną tożsamością wpisaną w politykę plemienną nie odnosi się w dosłowny sposób do brexitu. Wyraźnie można tu jednak dostrzec echo zasadniczych dla wyników głosowania w 2016 roku kwestii, poruszanych także m.in. w tetralogii powieściowej (Jesień, Zima, Wiosna i Lato) Ali Smith czy w książce Bernardine Evaristo pt. Dziewczyna, kobieta, inna. Chodzi mianowicie o różne sposoby rozumienia praw obywatelskich, powiązane z nimi możliwe przesunięcia w ramach tzw. polityki tożsamościowej oraz emigrację, a właściwie imigrację w kontekście brytyjskich lęków leżących 
u podstaw decyzji referendalnej, a podsycanych przez zwolenników zamknięcia granic państwowych Zjednoczonego Królestwa. The Wall Lanchestera pokazuje dalekosiężne skutki brexitu, opierając się na optymistycznym założeniu, że Wielka Brytania pozostanie oazą dobrobytu za cenę państwowej kontroli nad obywatelami (obowiązkowe czipy identyfikacyjne) i autorytaryzmu władzy. Służba wojskowa jest tu obowiązkiem każdego młodego człowieka, a zwalnia z niej tylko zobowiązanie do prokreacji. To w zasadzie służba wartownicza, na stanowiskach obronnych, ponieważ młodzi Brytyjczycy strzegą swych granic przed Innymi (Others). Średniej wielkości wyspa na zachodnich rubieżach Europy staje się upragnionym celem nielegalnej imigracji, której należy zapobiec za wszelką cenę. Struktury obronne mają zaś postać muru ciągnącego się wzdłuż wybrzeża całej Brytanii. Za murem jest tylko bezkres morza i zagrożenie w postaci „Innych”. Dopiero kiedy główny bohater zostaje skazany na banicję i musi radzić sobie w świecie zaludnionym przez owych Innych, zaczyna myśleć inaczej o swojej agonistycznie uformowanej tożsamości:

Wychowano mnie tak, bym nie myślał o tym, skąd Inni pochodzą albo kim są, bym takie myśli ignorował - byli po prostu Innymi. Ale może teraz, kiedy stałem się jednym z nich, przestali już być Innymi? Skoro ja byłem Innym i oni byli Innymi, może nikt z nas nie był Inny, za to staliśmy się nowymi Naszymi. Byłem zdezorientowany (Lanchester 2019: 203).

Wyraźnie zarysowany podział, podkreślony koniecznością obrony terytorium brytyjskiego, pojawia się w następstwie Zmiany (por. Lanchester 2019: 11), procesu, który stanowi w powieści ekwiwalent dawnego kryzysu, być może przeciągającej się katastrofy ekologicznej uniemożliwiającej normalną egzystencję poza Wyspami Brytyjskimi. Jest w tej wizji element ironii, ponieważ to Wielkiej Brytanii wieszczy się w następstwie brexitu katastrofę ekonomiczną, a także obniżenie standardów związanych z produkcją i dopuszczeniem na rynek żywności (np. planowane zniesienie ceł na słynne, odkażane chlorem amerykańskie kurczaki - zob. Schraer, Edgington 2019) oraz troską o środowisko. W powieści Lanchestera widać też wyraźnie, w jakim kierunku może zmierzać polityka odwołująca się do „suwerena” (powtarzane jak mantra jeszcze przez panią premier Theresę May: the people) i jego woli. Prędzej czy później konserwatyści - w imieniu i w rzekomym interesie suwerena - wprowadzają rządy autokratyczne i system wartości współgrający z państwem policyjnym. A wszystko dla dobra obywateli.

Apokalityczna wizja przyszłości Zjednoczonego Królestwa wyłania się także z popularnego brytyjskiego miniserialu pt. Years and Years (2019, twórca: 
Russell T. Davies; polski tytuł: Rok za rokiem). To obraz upadku i pozornego odradzania się postbrexitowego imperium, z wieloma satyrycznymi akcentami nawiązującymi do obecnych rządów Partii Konserwatywnej, a także wpływu na życie polityczne i nastroje społeczne ekstremistów spod znaku angielskiego nacjonalizmu. Emma Thompson w roli Vivienne Rook, przywódczyni partii „4 Stars” (Cztery gwiazdy), to synteza tego, co najbardziej demoniczne i destrukcyjne we współczesnej europejskiej polityce nie tylko wśród konserwatystów i nacjonalistów reprezentujących partię UKIP (United Kingdom Independence Party - Partię Niepodległości Zjednoczonego Królestwa pod wodzą Nigela Farage’a). Fanatyzm, skrajny oportunizm i brak jakichkolwiek hamulców moralnych cechuje przecież rozmaite, czasem bardzo wpływowe ugrupowania także w krajach członkowskich Unii Europejskiej. Warto również uważnie przyjrzeć się wykorzystaniu zdobyczy technologicznych do manipulowania opinią publiczną ${ }^{3}$ i swoistej inżynierii społecznej, polegającej na „społecznej produkcji moralnej obojętności” (ang. social production of moral indifference), którą diagnozował i przed którą ostrzegał już dawno Zygmunt Bauman (Bauman 1989: 18).

Bodaj najbardziej zjadliwą satyrą na rządy Torysów, a szczególnie premiera Johnsona, jest nowela Iana McEwana pt. The Cockroach (Karaluch). To opowieść pełna aluzji literackich (Przemiana Franza Kafki) i kulturowych, utrzymana w konwencji bajki antropomorficznie przedstawiającej owady. W tym ogólnym przeglądzie brytyjskich dyskursów kryzysowych chcemy zwrócić uwagę na wyjątkowo złośliwe, ale i celne nawiązanie przez jej autora do typowej dla kampanii sprzed referedum retoryki dehumanizującej obcych, imigrantów czy posługując się językiem powieści Lanchestera - Innych. McEwan konstruuje swój świat przedstawiony w taki sposób, by czytelnik stopniowo zdawał sobie sprawę z tego, że odzyskujący pewnego poranka świadomość karaluch w budynku na Downing Street nr 10 to premier Zjednoczonego Królestwa, Jim Sams, przyobleczony w powłokę cielesną znaną z mediów na całym świecie. Sugestia, że cały rząd konserwatystów doprowadzający, jak chce McEwan, do rewolucji ekonomicznej zwanej „rewersalizmem” (chodzi o odwrócenie obiegu pieniądza - od sprzedawcy lub usługodawcy do klienta) to owady tymczasowo udające ludzkie istoty, nawiązuje do rozmaitych teorii spiskowych przypisujących pochodzenie pozaziemskie lub gadzie elitom dzierżącym władzę nad „zwykłymi obywatelami"(zob. Conspiracy Theories, dostęp 2021). Tyle że populiści tacy jak Trump (i rzekomo zdekonspirowane przez niego słynne deep state) czy Johnson usiłują sytuować się po stronie demosu, ludu gotowego rozprawić się z elitami.

$3 \mathrm{Tu}$, obok wspomnianego miniserialu, pouczający okazuje się paradokument z 2019 roku pt. Brexit: the Uncivil War w reżyserii Toby’ego Haynesa $\mathrm{z}$ rewelacyjną główną rolą Benedicta Cumerbatcha jako Dominika Cummingsa. 
W Zjednoczonym Królestwie pielęgnującym tradycyjny system klasowy powieść McEwana zyskuje szczególnie ironiczny wymiar, skoro sam premier Johnson i jego kompani to śmietanka towarzyska wyedukowana w elitarnych, prywatnych szkołach i najczęściej dziedzicząca pokaźne majątki po swoich przodkach. Applebaum wskazuje na fasadowość tego politycznego teatrum, gdy wspomina Johnsona z 2014 roku, czyli z czasów piastowania przez niego stanowiska burmistrza kosmopolitycznego Londynu. Wówczas, jak przypomina Applebaum, miał on wygłosić wykład na temat demokracji ateńskiej, w którym to wychwalał takie jej przymioty, jak „wolność, otwartość, tolerancja”. Jednocześnie, zauważa autorka, ostrzegał przed „nowymi Spartanami”, którzy, podobnie jak ich protoplaści, ze względu na swoje „nieprzejednanie” i wojowniczą mentalność nie będą mieli wiele do zaoferowania w globalizującym się świecie. W późniejszym czasie, przy okazji innego spotkania, na pytanie o wyjście Wielkiej Brytanii z Unii Europejskiej Johnson odpowiedział jednoznacznie: „Nikt poważny nie chce opuszczać uE. Biznes tego nie chce. The City [londyńskie centrum finansowe - M.Z.W., R.B., L.D.] tego nie chce. To się nie wydarzy" (Applebaum 2020: 70). Według Applebaum Johnson jest przedstawicielem tej części elity, która dość swobodnie i w istocie obłudnie traktuje możliwe konsekwencje swoich działań. Dla nich rewolucja jest zabawą w nacjonalizm (O’Toole 2020: 63), bezkarną igraszką na pokładzie statku głupców, z którego zawsze można się ewakuować (por. McEwan 2019: 29). Tak zresztą czynią członkowie rządu Jima Samsa, uciekając z posiedzenia gabinetu po powtórnej metamorfozie jako zwykłe karaluchy. Nim to nastąpi, premier zaznacza, że powszechny chaos i tragedie na skalę narodową to już problem ludzi, a nie grupy owadów, którym zmiany wyszły wyłącznie na dobre.

\section{Północnoirlandzka schizofrenia}

Oczywiście, ze statku głupców nie wszyscy zdążą się ewakuować. Wiedzą o tym najlepiej pisarze z Irlandii Północnej, gdzie - w Belfaście - wybudowano i w 1912 roku zwodowano Titanica. Po referendum brexitowym w 2016 roku Irlandia Północna stała się kością niezgody między Wielką Brytanią a Unią Europejską broniącą interesów Republiki Irlandii. Problemów nie rozwiązał specjalny protokół dotyczący właśnie Irlandii Północnej (The Northern Ireland Protocol 2020), bez którego w ogóle nie doszłoby do porozumienia w sprawie wyjścia Zjednoczonego Królestwa z Unii Europejskiej. Potencjalne napięcie na granicy lądowej między Irlandią Północną i Republiką Irlandii pozostającą w Unii Europejskiej przeniosło się na granicę morską, gdzie w portach irlandzkich (głównie w Larne i Belfaście) dokonuje się odprawy celnej i kontroli 
fitosanitarnej zgodnie z unijnymi wymogami. To rodzi konflity i napięcia podsycane przez północnoirlandzkich unionistów, pragnących jak najściślejszych więzów z Wielką Brytanią (Edgington, Morris 2021), nawet jeśli w 2016 roku wyraźna większość mieszkańców Irlandii Północnej głosujących w referendum brexitowym opowiedziała się za pozostaniem w Unii Europejskiej (McCann, Hainsworth 2016: 9).

Na tle brytyjskiej prozy odwołującej się - pośrednio lub bezpośrednio do kryzysu spowodowanego brexitem literatura irlandzka zachowuje większą ciągłość formalną i tematyczną. Brexit, a właściwie samo referendum, wywołał w prozie północnoirlandzkiej silne skojarzenia z konfliktem trzydziestoletnim zwanym the Troubles (1969-1998), a będącym po prostu wojną domową (por. Jarniewicz 2000: 230) między nacjonalistami irlandzkimi i nacjonalistami brytyjskimi. Brexit to zdaniem Fintana O'Toola nic innego jak erupcja angielskiego (nie brytyjskiego!) nacjonalizmu (O’Tool 2020: 12-13), więc dwudziestowieczna historia Irlandii może być pożytecznym punktem odniesienia dla badaczy szukających analogii. Literatura północnoirlandzka po referendum w 2016 roku stanowi zaś mieszankę nostalgii oraz gorzkiej ironii oddającej nastroje społeczeństwa pozbawionego złudzeń i jakiegokolwiek wpływu na losy całego Królestwa. Taki zmierzch wiary w sprawczość i podmiotowość obywatelską widać chociażby w niezwykle zabawnej i pouczającej książeczce zbierającej wpisy z konta twitterowego irlandzkiej granicy. Autorką wpisów jest sama granica - żaden pisarz z imienia i nazwiska nie przyznał się do roli intersemiotycznego tłumacza.

A może irlandzka granica jednak potrafi przemawiać ludzkim głosem? Czytając I am the Border, so I am, bez trudu natrafimy na inteligentne, dobrze sformułowane sugestie najwyraźniej ignorowane przez brytyjskich Torysów:

Po blisko 100 latach bycia granicą, najważniejsze, czego się nauczyłam, to że granice są najbardziej tchórzliwą formą interakcji między ludźmi. Otwarcie się na obcych, otwarcie się na nowe, nieznane i niespodziewane - to jest dopiero odwaga (@BorderIrish 2019: 249).

O fenomenie granicy i niepożądanych skutków, jakie niesie ze sobą jej ewentualne przywrócenie (co jest/może być końcowym efektem brexitu), pisze również Glenn Patterson, jeden z bardziej reprezentatywnych pisarzy północnoirlandzkich. W książce Backstop Land (Kraj backstopu) wspomina czas referendum, zwracając szczególną uwagę na to, iż większość miejscowej ludności była za pozostaniem w UE. Absolutnie nie może to dziwić, jeśli weźmiemy pod uwagę lata doświadczeń ze światem podzielonych społeczności, podzielonych dzielnic 
czy nawet podzielonych ulic. Jak pisze Patterson, głosując przeciw opuszczaniu wspólnoty, ludzie kierowali się najwyraźniej podskórnym przeświadczeniem, iż nie jest to droga ku konstruktywnym rozwiązaniom. Paradoksalnie, według autora, znaczna część tych osób mogła/może zacząć się zastanawiać, czy ich „interesy i aspiracje nie będą lepiej zabezpieczone w Zjednoczonej Irlandii” (Patterson 2019: 50). W powyższym kontekście przywracanie granic, wznoszenie murów stało się nie tylko objawem błędnej (a często i obłędnej) polityki, ale stanem umysłu, którego odzwierciedlenie niejednokrotnie odnajdujemy we współczesnym dyskursie literackim.

Jeszcze dziesięć lat temu granica nie cieszyła się specjalnym zainteresowaniem badaczy, za to w drugiej dekadzie xxI wieku, szczególnie po referendum brexitowym w 2016 roku, rynek wydawniczy wprost zalała fala opracowań na jej temat ${ }^{4}$. Z kolei w tekstach literackich była ona obecna od dawna - istnieją też polskojęzyczne opracowania odwołujące się do korpusu tekstów poruszających problem granicy (Drong 2019: 138-142, 2021: 1-16). W 1987 roku ukazała się Bad Blood (Zła krew), opowieść Colma Toíbína o wędrówce autora wzdłuż granicy i spotkaniach z ludźmi pogranicza. Po referendum brexitowym podobne przedsięwzięcie opisał Garrett Carr w The Rule of the Land (Pod panowaniem ziemi), sięgając w głąb irlandzkiej historii i kultury. Już na początku xxı wieku granica stała się popularnym lejtmotywem wielu kryminałów, w których - jak np. w twórczości Briana McGillowaya - trupy odnajdywano na terenie o trudnej do ustalenia jurysdykcji (Borderlands - Na granicy z 2007 roku). Z podobnego okresu pochodzi powieść dla młodzieży i dorosłych pióra Siobhan Dowd pt. Bog Child (Dziecko z bagien), nawiązująca do poezji Seamusa Heaneya, a przede wszystkim do odkryć archeologicznych w Jutlandii. Tam również dobrze zakonserwowane w torfie zwłoki odnajdują się przypadkiem tuż przy granicy.

By uwypuklić istotne kwestie geopolityczne w Irlandii Północnej, warto jeszcze zwrócić uwagę na wydaną w 2018 roku powieść Davida Parka pt. Travelling in a Strange Land (Przemierzając obcy kraj), której akcja w dużej mierze rozgrywa się w Belfaście. Kwestia granicy i problemy wywołane brexitem są tu istotnym elementem powiązanym z osobistą traumą głównego bohatera, który stracił syna. Tom podróżuje do Sunderland, gdzie utknął jego chory (drugi) syn, studiujący na angielskiej uczelni. By do niego dotrzeć, ojciec musi przedostać się w trudnych, zimowych warunkach przez dwie symboliczne granice - najpierw promem pokonuje granicę na Morzu Irlandzkim, formalnie nieistniejącą, ale już (jeszcze?) funkcjonującą w kontekście różnic prawnych i obyczajowych, które zakazują aborcji w Irlandii Północnej, a dopuszczają ją w Wielkiej Brytanii. Tom

4 Z ostatniej dekady warto wymienić przynajmniej trzy przykłady: Patterson 2013; Moore 2019; Ferriter 2019. 
ma tego świadomość, płynąc promem w kierunku większej z Wysp Brytyjskich, która dla irlandzkich kobiet „noszących zgryzotę w swoim łonie” (Park 2018: 14) była do niedawna wybawieniem. Po raz drugi bohater wraca myślami do granic i podziałów i snuje wspomnienia, kiedy mija Wał Hadriana stanowiący kiedyś (wybudowano go w II wieku n.e.) fortyfikację oddzielającą Brytanię pod panowaniem rzymskim od Kaledonii zamieszkałej przez wojownicze plemię Piktów. Tomowi Wał Hadriana przywodzi na myśl tzw. ściany pokoju do dzisiaj oddzielające w Belfaście dwie zwaśnione wspólnoty - nacjonalistyczną (katolicką) i unionistyczną (protestancką):

W Belfaście wykorzystaliśmy, jak się da, nasz niedawny konflikt i prezentujemy go turystom w ocenzurowanej wersji w ramach wycieczek autobusem lub taksówką podwożącą ich pod murale i ścianę pokoju. Całe dekady po tym, jak Niemcy pozbyli się muru berlińskiego, my wciąż mamy własny i nigdy nie zrozumiem, dlaczego nazywamy go ścianą pokoju, skoro jego pierwotnym celem było zapobieganie swobodnym, wzajemnym atakom ze strony mieszkających tuż obok siebie społeczności (Park 2018: 80).

Warto dodać, że pierwsze, prowizoryczne ściany pokoju postawili w 1969 roku w Belfaście żołnierze brytyjscy usiłujący rozdzielić dwa wrogo nastawione do siebie północnoirlandzkie plemiona.

\section{Europejski horyzont po brexicie}

Zastanawiając się nad konsekwencjami brexitu, Upstone stawia pytanie dotyczące potencjalnych odpowiedzi pola literackiego na zaistniałe wyzwania społeczno-polityczne. Według badaczki należy oczekiwać, iż obrany kierunek będzie dwuwektorowy i będzie tworzył lub zamykał przestrzeń dla narracji „kształtujących idee różnorodności i tolerancji” (Upstone 2019: 56). Choć sam fakt wyjścia ze struktur Unii Europejskiej wskazuje na tendencje dośrodkowe i homogenizacyjne, to dyskursy: literacki i akademicki zarysowują szerszą perspektywę, w której trudno szukać pozytywnych ocen tego, co zapoczątkował rok 2016. W tym kontekście opinia Penelope Lively, wyrażona w liście It Began on a Field in Normandy (Wszystko zaczęło się na polu w Normandii) ${ }^{5}$,

5 Wspomniane wyżej listy pochodzą z tomu A Love Letter to Europe. An Outpouring of Sadness and Hope from Writers, Thinkers and Artists, który powstał po referendum i był odpowiedzią pisarzy i intelektualistów na dramatyczne zakwestionowanie części własnej europejskiej tożsamości. 
a dotycząca tego, jak europejska różnorodność skłania Brytyjczyków do „myślenia inaczej” oraz jak bardzo wieloaspektowość wspólnoty ułatwiała eksponowanie poszczególnych tożsamości narodowych (Lively 2019: 258), może być uznana za wspólny mianownik dla większości omawianych w tym numerze „Porównań" tekstów prymarnych, a przede wszystkim dla krytycznych analiz tu przedstawionych. Wielu spośród pisarzy i badaczy podpisałoby się zapewne pod listem A New European Song (Nowa europejska pieśń), który Mary Beard napisała kilka tygodni po referendum. Podkreślała w nim ścisłą współpracę między Zjednoczonym Królestwem a Europą kontynentalną, która to współpraca na przestrzeni dekad, dzięki „mieszance kultur, języków i różnych tradycji”, przynosiła tak liczne owoce i „poszerzała nasze horyzonty” (Beard 2019: 593, wyróż. - R.B., L.D., M.Z.W.).

Warto też pamiętać, że niemal wszechobecny w tym numerze „Porównañ” brexit to zaledwie synekdocha kryzysu (czy raczej mnogości kryzysów) we współczesnej Europie. Swoistej dezintegracji europejskiej towarzyszy coś, co Bauman nazwał w Retrotopii „powrotem do plemion” (Bauman 2018: 87) - zjawisko nie tyle opozycyjne wobec agresywnego nacjonalizmu etnicznego, ile często symbiotycznie z nim skorelowane. Wprowadzając czytelników w problematykę wzajemnych zależności społeczno-politycznych i literackich na Wyspach Brytyjskich (wątek dominujący w całym numerze), pragniemy podkreślić znaczenie odmiennych od plemienności postaw i afektów. Ogólna konkluzja niniejszego przeglądu palących - i zapalnych - kwestii oraz źródeł kryzysu okołobrexitowego, jak i zdecydowanej większości artykułów goszczących na łamach tego numeru „Porównań” jest prosta i jednoznaczna: jeśli przywoływane w tym kontekście utwory literackie można uznać za adekwatne świadectwo dominujących nastrojów i refleksji, to współczesną kulturę europejską cechuje godna podziwu odporność na insularny separatyzm czy śródlądowy integryzm. To nie populistyczni politycy, a właśnie kultura kształtuje złożoną, pluralistyczną (czy wręcz kosmopolityczną - Shaw 2017) tożsamość ponowoczesnej Europy, a także tożsamość ponadnarodowo definiujących swoją wspólnotę obywateli jednej z najstarszych utopii ufundowanych na tym, co zawdzięczamy - jako gatunek ludzki - umiejętności opowiadania historii wyzwalających empatię niezależną od ideowych podziałów i plemiennych antagonizmów. 


\section{| Bibliografia}

@BorderIrish (2019), I am the Border, so I am, HarperCollinsPublishers, London. Applebaum Anne (2020), Twilight of Democracy. The Seductive Lure of Authoritarianism, Doubleday, New York.

Bauman Zygmunt (1989), Modernity and the Holocaust, Polity Press, Cambridge. Bauman Zygmunt (2018), Retrotopia, przeł. Karolina Lebek, PwN, Warszawa. Beard Mary (2019), A New European Song, w: A Love Letter to Europe: An Outpouring of Sadness and Hope from Writers, Thinkers and Artists, red. Mary Beard i in., Hodder \& Stoughton, Kindle Edition.

Blair Tony (2010), A Journey, Hutchinson, London.

Buckledee Steve (2018), Language of Brexit: How Britain Talked Its Way Out of the European Union, London and New York, Bloomsbury Academic.

Coe Jonathan (2018), Middle England, Penguin Books, London.

Conspiracy Theories: The Reptilian Elite, “Time”, https://tinyurl.com/3mr48htd [dostęp: 30.05.2021].

Drong Leszek (2019), Tropy konfliktu. Retoryka pamięci kulturowej we wspótczesnej powieści północnoirlandzkiej, Wydawnictwo Uniwersytetu Śląskiego, Katowice.

Drong Leszek (2021), Ograniczanie Irlandii. Badania (po)nad granicami i literatura rozbiorowa, „Śląskie Studia Polonistyczne”, t. 17, nr 1, s. 1-16, https://doi.org/10.31261/SSP.2021.17.01.

Eaglestone Robert, red. (2018), Brexit and Literature: Critical and Cultural Responses, London and New York, Routledge.

Edgington Tom, Morris Chris (2021), Brexit: What is the Northern Ireland Protocol and why are there checks?, "Ввс News", 15.03, https://www.bbc.com/news/explainers-53724381 [dostęp: 30.05.2021].

Ferriter Diarmaid (2019), The Border: The Legacy of a Century of Anglo-Irish Politics, Profile Books, London.

Fukuyama Francis (2019), Identity. Contemporary Identity Politics and the Struggle for Recognition, Profile Books, London.

Hamid Mohsin (2018), Drzwi na Zachód, przeł. Witold Kurylak, Sonia Draga, Katowice.

Hesk Jon (2019), Boris Johnson and the seductive sophistry of slogans, "Ancient and Modern Rhetoric", o1.10, https://tinyurl.com/29su4fbf [dostęp: 30.05.2021].

Jarniewicz Jerzy (200o), Hieroglify historii, w: tenże, Lista obecności. Szkice o dwudziestowiecznej prozie brytyjskiej i irlandzkiej, Rebis, Poznań, s. 227-231.

Lanchester John (2019), The Wall, Faber \& Faber, London. 
Lively Penelope (2019), It Began on a Field in Normandy, w: A Love Letter to Europe: An Outpouring of Sadness and Hope from Writers, Thinkers and Artists, red. Mary Beard i in., Hodder \& Stoughton, Kindle Edition.

McCann Gerard, Hainsworth Paul (2016), Brexit and Northern Ireland: the 2016 referendum on the United Kingdom's membership of the European Union, "Irish Political Studies", 32: 2, s. 1-14, https://doi.org/10.1080/07907184.2016.1243530

McEwan Ian (2019), The Cockroach, Jonathan Cape, London.

Moore Cormac (2019), Birth of the Border: The Impact of Partition in Ireland, Merrion Press, Newbridge.

O'Toole Fintan (2020), Three Years in Hell: The Brexit Chronicles, Head of Zeus, London.

Park David (2018), Travelling in a Strange Land, Bloomsbury Publishing, London. Patterson Glenn (2019), Backstop Land, Head of Zeus, London.

Patterson Henry (2013), Ireland's Violent Frontier: The Border and Anglo-Irish Relations During the Troubles, Palgrave Macmillan, London.

Perrigo Billy (2019), "Get Brexit Done." The 3 Words That Helped Boris Johnson Win Britain's 2019 Election, “Time”, 13.12, https://tinyurl.com/ypajkxat [dostęp: 30.05.2021].

Schlögel Karl (2009), W przestrzeni czas czytamy. O historii cywilizacji i geopolityce, przeł. Izabela Drozdowska, Łukasz Musiał, Poznańska Biblioteka Niemiecka, Poznań.

Schraer Rachel, Edgington Tom (2019), Chlorinated chicken: How safe is it?, “ввс Reality Check”, 05.03, https://www.bbc.com/news/uk-47440562 [dostęp: 30.05.2021].

Shaw Kristian (2017), Cosmopolitanism in Twenty-First Century Fiction, Palgrave Macmillan, London.

Shaw, Kristian (2021), Brexlit: British Literature and the European Project, Bloomsbury Publishing, London.

Skrendo Andrzej (2019), Pisarz jako przewodnik duchowy w: Geoliteratura. Przewodnik, bedeker, poradnik, red. Jerzy Madejski, Sławomir Iwasiow, Universitas, Kraków, s. 23-40.

Sobolewska Maria, Ford Robert (2020), Brexitland: Identity, Deversity and the Reshaping of British Politics, Cambridge University Press, Cambridge.

The Northern Ireland Protocol (2020), https://tinyurl.com/5ap6um7b [dostęp: 30.05.2021].

Upstone Sara (2018), Do novels tell us how to vote?, w: Brexit and Literature: Critical and Cultural Responses, red. Robert Eaglestone, Routledge, London and New York, s. 44-58.

Years and Years, twórca: Russell T. Davies, Red Production Company і нво, 2019. 


\section{| Abstrakt}

Ryszard Bartnik, Leszek Drong, MaŁgorzata Zduniak-Wiktorowicz Krzywe lustra kryzysu? Konflikty i podziały społeczno-polityczne związane $\mathrm{z}$ brexitem we współczesnych powieściach z Wysp Brytyjskich

Celem niniejszego artykułu jest zarysowanie tła literackiego, a także filozoficznego i społeczno-politycznego związanego z gatunkiem, który w 2017 roku Jon Day określił jako „Brexlit”. Artykuł skupia się na kluczowych powieściach brytyjskich, irlandzkich, a także tych utworach anglojęzycznych spoza kręgu kulturowego Wysp Brytyjskich, które zawierają w swojej treści, a czasem również formie, przesłanie dotyczące decyzji podjętej w referendum z 2016 roku, tj. decyzji o opuszczeniu przez Zjednoczone Królestwo Unii Europejskiej. Świat powieściowy w szczególnie przenikliwy i wrażliwy sposób zareagował na przemiany społeczno-polityczne w Wielkiej Brytanii oraz, przynajmniej częściowo, w Irlandii Północnej. Podstawowe pytanie, jakie stawiamy sobie tutaj, dotyczy roli dyskursu literackiego w konfrontacji z rzeczywistością społeczno-polityczną oraz rozmaitymi ideologiami oddziałującymi na mieszkańców Zjednoczonego Królestwa. Czy powieści z ostatnich kilku lat pokazują alternatywne scenariusze polityczne? Czy, z nieuniknionym poślizgiem komentując rzeczywistość europejską, są jedynie przesuniętym w czasie i załamanym przez światło ideologii odbiciem zmian społecznych - krzywymi lustrami kryzysu? Czy może istnieje w dyskursie powieściowym wciąż niedostatecznie wykorzystany potencjał do kształtowania i urzeczywistniania narracji fikcyjnych z myślą o lepszej przyszłości kultury i całej sfery publicznej na Wyspach? Odpowiedź, jaką tu proponujemy, skupia się na podtrzymaniu ścisłych związków między ewolucją brytyjskiego rozumienia świata społeczno-politycznego a kulturą europejską sensu largo. Także kulturą antycypowaną lub projektowaną na najbliższą przyszłość. Pisarze brytyjscy oraz irlandzcy, odnosząc się do brexitu, niemal bez wyjątku akcentują przesłanie o zachowaniu ponadpolitycznej i ponadnarodowej wspólnoty - nawet w obliczu niedawnych podziałów.

Słowa kluczowe: BrexLit; brexit; współczesna powieść anglojęzyczna; wspólnota; nacjonalizm 


\section{| Abstract}

Ryszard Bartnik, Leszek Drong, MaŁgorzata Zduniak-Wiktorowicz The Crooked Mirrors of the Crisis? Brexit-Related Socio-Political Conflicts and Divisions in Contemporary British and Irish Fiction

The aim of this article is to offer a literary, philosophical and socio-political background to the development of BrexLit, defined by Jon Day (in 2017) as an emerging genre of literature. Our article's focus is on British and Irish novels, as well as other anglophone fiction from outside the British Isles, which communicate a message to do with the 2016 referendum resulting in the departure of the United Kingdom from the European Union. Novelists have developed a particularly acute and sensitive response to the socio-political transformations in Great Britain and, to a large extent, in Northern Ireland. The key question we address here concerns the role of literary discourse confronting socio-political realities and various ideologies that have affected people living in the UK. Do the novels published over the last few years reflect alternative political scenarios? Or, by involving an inevitable temporal slippage in commenting on European realities, are they only a displaced and ideologically refracted reflection of the social changes, i.e., crooked mirrors of the crisis? Is there, in the contemporary novel, a still inadequately utilized potential to shape and implement fictional narratives with a view to a better future of the culture-and the whole public sphere-in the British Isles? Our answers consist in maintaining close ties between the evolution of the British assessment of sociopolitical realities and European culture at large, including the sort of culture that is only anticipated and projected onto the future. Both British and Irish writers who address Brexit as an issue nearly unanimously emphasize a message about upholding and affirming a supranational community above politics, even in the face of recent rifts and divisions.

Keywords: BrexLit; Brexit; contemporary British and Irish fiction; nationalism; community

\section{| Biogramy}

Ryszard Bartnik - dr hab., zatrudniony na stanowisku profesora uczelni na Wydziale Anglistyki Uniwersytetu im. Adama Mickiewicza (Zakład Literatury Angielskiej i Lingwistyki Literackiej). Jego głównym obszarem zainteresowań badawczych jest współczesna literatura brytyjska/angielska/północnoirlandzka/południowoafrykańska. Główny nacisk w swoich badaniach kładzie na sposoby przedstawiania, 
w ramach dyskursu literackiego, takich kwestii jak: trauma, pamięć, przemoc, pojednanie, społeczeństwa podzielone, ale także fundamentalizm, ideologia. Rezultatem powyższych prac badawczych jest wydana w 2017 roku książka poświęcona południowoafrykańskim i północnoirlandzkim narracjom literackim powstałym po okresach przełomu politycznego, odpowiednio w roku 1994 i 1998. W ostatnim czasie, to jest w latach 2020-2021, jego uwaga skupia się na zawirowaniach okołobrexitowych i związanych z brexitem korelacjach pomiędzy dyskursem literackim a dyskursem społeczno-politycznym.

E-mail: rbartnik@amu.edu.pl

ORCID: 0000-0002-3675-0650

Leszek Drong - prof. dr hab., anglista związany z Instytutem Literaturoznawstwa na Uniwersytecie Śląskim w Katowicach. Obecnie pełni także funkcję prodziekana ds. badań naukowych Wydziału Humanistycznego. Od 2019 roku jest prezesem Polskiego Towarzystwa Badań Irlandystycznych. Jego najnowsza monografia nosi tytuł: Tropy konfliktu. Retoryka pamięci kulturowej we współczesnej powieści północnoirlandzkiej (Katowice 2019). Publikował ostatnio w takich czasopismach jak „Critique: Studies in Contemporary fiction”, „Estudios Irlandeses”, „Studia Litteraria Universitatis Iagellonicae Cracoviensis” czy „Przegląd kulturoznawczy”. Jego zainteresowania badawcze oscylują wokół irlandystyki (szczególnie Irlandia Północna) oraz badań nad pamięcią kulturową w kontekście geopolityki europejskiej (badania nad granicami - border studies).

E-mail: leszek.drong@us.edu.pl

ORCID: 0000-0001-8395-013X

Małgorzata Zduniak-Wiktorowicz - dr hab., prof. UAM, pracuje na Wydziale Filologii Polskiej i Klasycznej, gdzie prowadzi zajęcia dla cudzoziemców. Zajmuje się głównie polsko-niemieckimi dyskursami, polską literaturą w Niemczech, w tym niemiecko-polską prozą migracyjną, studiami postkolonialnymi i postzależnościowymi. Autorka monografii: Filologia w kontakcie. Polonistyka, germanistyka, postkolonializm, Poznań 2018.

E-mail: mzduniak@amu.edu.pl

ORCID: 0000-0002-8025-3993 